\title{
Erratum to: Structural, thermal kinetics and thermodynamics study of new mixed ligand zinc complexes
}

Niaz Muhammad ${ }^{1} \cdot$ Muhammad Ikram $^{1} \cdot$ Sadia Rehman $^{1} \cdot$ Mohammad Ibrahim ${ }^{1} \cdot$ Viola $^{1} \cdot$ Carola Schulzke $^{2}$

Published online: 2 November 2016

(C) Akadémiai Kiadó, Budapest, Hungary 2016

\section{Erratum to: J Therm Anal Calorim}

\section{DOI: $10.1007 / \mathrm{s} 10973-016-5842-7$}

In the original publication of the article, the fourth and fifth author names were combined and published as Mohammad Ibrahim Viola. The correct author group is given in this erratum.

The original article was corrected.

The online version of the original article can be found under doi:10.1007/s10973-016-5842-7.

Niaz Muhammad

drniaz@awkum.edu.pk

$\triangle$ Muhammad Ikram

ikram@awkum.edu.pk

1 Department of Chemistry, Abdul Wali Khan University, Mardan, Pakistan

2 Institut für Biochemie, Ernst-Moritz-Arndt Universität Greifswald, Felix-Hausdorff-Straße 4, 17487 Greifswald, Germany 